\title{
Notch1 activation reduces proliferation in the multipotent hematopoietic progenitor cell line FDCP-mix through a p53-dependent pathway but Notch1 effects on myeloid and erythroid differentiation are independent of p53
}

\author{
K Henning ${ }^{1,6}$, J Heering ${ }^{1,6,7}$, R Schwanbeck ${ }^{1,6}$, T Schroeder ${ }^{2,6}$, H Helmbold ${ }^{3}$, H Schäfer ${ }^{4}$, W Deppert ${ }^{3}$, E Kim ${ }^{5}$ and U Just ${ }^{\star, 1}$
}

Signaling mediated by activation of the transmembrane receptor Notch influences cell-fate decisions, differentiation, proliferation, and cell survival. Activated Notch reduces proliferation by altering cell-cycle kinetics and promotes differentiation in hematopoietic progenitor cells. Here, we investigated if the $G_{1}$ arrest and differentiation induced by activated mNotch1 are dependent on tumor suppressor p53, a critical mediator of cellular growth arrest. Multipotent wild-type p53-expressing (p53 ${ }^{\mathrm{wt}}$ ) and p53-deficient ( $p 53^{\text {null }}$ ) hematopoietic progenitor cell lines (FDCP-mix) carrying an inducible mNotch1 system were used to investigate the effects of proliferation and differentiation upon mNotch1 signaling. While activated Notch reduced proliferation of $p 53^{\text {wt }}$-cells, no change was observed in p53 $3^{\text {null }}$-cells. Activated Notch upregulated the p53 target p2 $1^{\text {cip/waf }}$ in p $53^{\text {wt }}$-cells, but not in $\mathrm{p} 53^{\text {null }}$-cells. Induction of the p21 ${ }^{\text {cip/waf }}$ gene by activated Notch was mediated by increased binding of p53 to p53-binding sites in the p21 $1^{\mathrm{cip} / \mathrm{waf}}$ promoter and was independent of the canonical RBP-J binding site. Re-expression of p53 $3^{\mathrm{wt}}$ in p53 $3^{\text {null }}$ cells restored the inhibition of proliferation by activated Notch. Thus, activated Notch inhibits proliferation of multipotent hematopoietic progenitor cells via a p53-dependent pathway. In contrast, myeloid and erythroid differentiation was similarly induced in $\mathrm{p} 53^{\mathrm{wt}}$ and $\mathrm{p} 53^{\text {null }}$ cells. These data suggest that Notch signaling triggers two distinct pathways, a p53-dependent one leading to a block in proliferation and a p53-independent one promoting differentiation.

Cell Death and Differentiation (2008) 15, 398-407; doi:10.1038/sj.cdd.4402277; published online 30 November 2007

Notch proteins are a family of highly conserved transmembrane receptors that transduce signals involved in the control of cell fate; differentiation, proliferation, and apoptosis in a cell context-dependent manner (reviewed by Wilson and Radtke, Lai, and Hurlbut et al. ${ }^{1-3}$ ). Depending on the cell type and other signals present for the receiving cell, Notch signaling can inhibit or delay differentiation, or promote differentiation. Similarly, Notch activation can induce cell cycle progression thereby increasing cell proliferation, while under different conditions it blocks cell cycle progression leading to growth arrest. Further, Notch activation can influence apoptosis positively or negatively.

Notch receptors are activated by specific transmembrane ligands of the Delta and Serrate/Jagged family. After ligand binding, the intracellular domain of Notch $\left(\right.$ Notch $\left.^{1 \mathrm{C}}\right)$ is proteolytically cleaved from the transmembrane region and translocates to the nucleus, where it associates with the transcriptional repressor RBP-J also termed CBF1. ${ }^{4}$ After binding of Notch ${ }^{\text {IC }}$, RBP-J is converted to a transcriptional activator and in conjunction with chromatin remodeling

\footnotetext{
${ }^{1}$ Department of Biochemistry, Christian-Albrechts-University of Kiel, Olshausenstraße 40, Kiel, Germany; ${ }^{2}$ Department of Stem Cell Research, GSF, Ingolstaedter Landstr. 1, Munich, Germany; ${ }^{3}$ Department of Tumor Virology, Heinrich-Pette-Institute, Martinistr. 52, Hamburg, Germany; ${ }^{4}$ Laboratory of Molecular Gastroenterology, 1st Department of Medicine, Christian-Albrechts-University of Kiel, Schittenhelmstr. 12, Kiel, Germany and ${ }^{5}$ Laboratory of Neurooncology, Department of Neurosurgery, Georg-August-University of Göttingen, Robert-Koch-Str. 40, Göttingen, Germany

*Corresponding author: U Just, Department of Biochemistry, Christian-Albrechts-University of Kiel, Olshausenstraße 40, Kiel 24098, Germany.

Tel: 49431880 2513; Fax: 49431880 2609; E-mail: ujust@biochem.uni-kiel.de

${ }^{6}$ These authors contributed equally to this work.

${ }^{7}$ Present address: Department for Cell Biology and Immunology, University of Stuttgart, Allmandring 31, Stuttgart 70569, Germany.

Keywords: Notch; p53; proliferation; hematopoiesis; FDCP-mix cells

Abbreviations: p53 $3^{\text {wt }}$, wild type p53; p53 ${ }^{\text {null }}$, p53-deficient; FDCP-mix, factor-dependent cell established at the Paterson Institute with mixed differentiation potential; mNotch1, murine Notch1; Notch ${ }^{\mathrm{LC}}$, intracellular domain of Notch; RBP-J, recombination recognition sequence binding protein at the $\mathrm{J} \kappa$ site; Hes, hairy and enhancer of split; Hey/Herp, Hes-related repressor; $\mathrm{mN} 1^{1 \mathrm{C}}$, intracellular domain of murine Notch1; NERT, $\mathrm{mN} 1^{1 \mathrm{C}}$ fused to the hormone binding domain of the human estrogen receptor tamoxifen-sensitive mutant; ERT, estrogen receptor tamoxifen-sensitive mutant; rneo, retroviral control vector carrying the neomyin resistance gene; rNERTneo, retroviral control vector carrying the NERT and neomyin resistance gene; rNERTneo FDCP-mix, FDCP-mix cells expressing an OHT-inducible form of Notch ${ }^{\text {IC }}$; rneo FDCP-mix, FDCP-mix cells carrying the retroviral control vector conferring neomycin resistance; G418, neomycin; OHT, 4-hydroxytamoxifen; CFSE, carboxyfluorescein diacetate succinimidyl ester; p21RBP-Jmut promoter, p21 promoter compromised in RBP-J binding; IMDM, Iscove's modified Dulbecco's medium; FCS, fetal calf serum; PE, Phycoerytrin; APC, allophycocyanin; PBS, phosphate-buffered saline; RT, room temperature; p21luc, reporter plasmid carrying a luciferase gene under the control of the p21 promoter; p21 p53BS1luc, p21 promoter lacking the first p53 binding site; p21 p53BS2luc, p21 promoter lacking the second p53 binding site; p21 $\mathrm{p} 53 \mathrm{BS} 1+2$ luc, p21 promoter lacking both p53 binding sites; ChIP, chromatin immunoprecipitation

Received 22.2.07; revised 05.10.07; accepted 19.10.07; Edited by M Oren; published online 30.11 .07
} 
enzymes, components of the transcriptional machinery and the activity of other cofactors induces transcription of downstream target genes, including genes of the Hes (Enhancer of Split) and Hey (also called Hes-related repressor Herp, Hesr, Hrt, CHF, gridlock) family. ${ }^{1,2}$ Recently, two proteins of the Hes/Hey basic helix-loop-helix transcription factor family, Hes1 and Hey1, were found in a screen for regulators of p53 activity. ${ }^{5}$ However, little is known about the biological significance of Hes1- and Hey1-dependent regulation of p53 activity in regard to Notch signaling.

The tumor suppressor protein p53 plays a critical role in maintaining cellular homeostasis both in normal development and following various cellular stresses including DNA damage and oncogene activation. ${ }^{6}$ After activation, it initiates a transcriptional program that can result in cell cycle arrest or apoptosis depending on the type and extent of the stimulus. Recently, we reported that activated Notch1 inhibits proliferation of hematopoietic progenitor cells due to cell cycle arrest in $\mathrm{G}_{0} / \mathrm{G}_{1}{ }^{7}$ and promotes myeloid differentiation. ${ }^{8,9}$ In this study, we examine whether p53 is required for these Notch-mediated effects. Our results show that Notch signaling inhibits proliferation via a p53-dependent mechanism involving upregulation of p21 expression while induction of myeloid and erythroid differentiation is p53 independent.

\section{Results}

Generation of $p 53^{\text {null }}$ FDCP-mix cell lines expressing a conditional activated $\mathbf{m N o t c h} 1^{1 \mathrm{C}}$. To determine whether p53 has a role in mediating the Notch1-induced cell cycle block and/or myeloid differentiation of hematopoietic progenitor cells, we generated $p 53^{\text {null }}$ FDCP-mix cells clones expressing an inducible form of the constitutively active intracellular part of murine Notch1. Like the FDCP-mix cells lines A4 or A7, p53 ${ }^{\text {null }}$ FDCP-mix cells are strictly factor-dependent hematopoietic progenitor cell lines that differentiate in a multilineage response to physiological regulators for differentiation, such as stromal cells or hematopoietic cytokines. ${ }^{10-12}$ Both were established from murine long-term cultures in the same way and share many characteristics with primitive hematopoietic progenitor cells. ${ }^{10,13}$ First, we confirmed that the p53 pathway was functional in FDCP-mix A7 cells and not responsive in p53 ${ }^{\text {null }}$ FDCP-mix cells (Figure 1a). Next, p53 ${ }^{\text {null }}$ FDCP-mix cells were transfected by electroporation with a retroviral vector carrying the $\mathrm{mN} 1^{1 \mathrm{C}}$ fused to the hormone binding domain of the human estrogen receptor $\left(\mathrm{NERT}^{9}\right)$, which was used previously to establish A7 FDCP-mix cells with an inducible Notch $1 .{ }^{8}$ As a control, cells were transfected with a control vector that does not contain the NERT cDNA (rneo). Both vectors confer G418 (neomycin) resistance to transfected cells. To ensure functionality and a tight regulation of the Notch-signaling pathway, clones were then analyzed for the expression of the NERT protein (Figure $1 \mathrm{~b}$ ) and further selected by testing for transactivation of the RBP-J pathway in the presence or absence of 4-hydroxytamoxifen (OHT) (Figure 1c). In the absence of $\mathrm{OHT}$, no transactivation was observed. After addition of OHT, the RBP-J pathway was transactivated in a concentration-dependent manner in all a

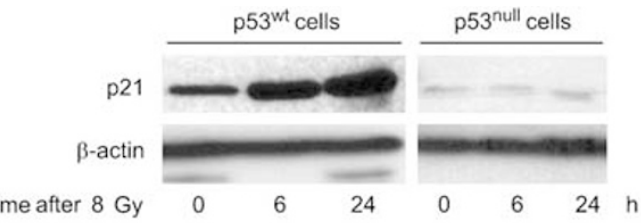

b
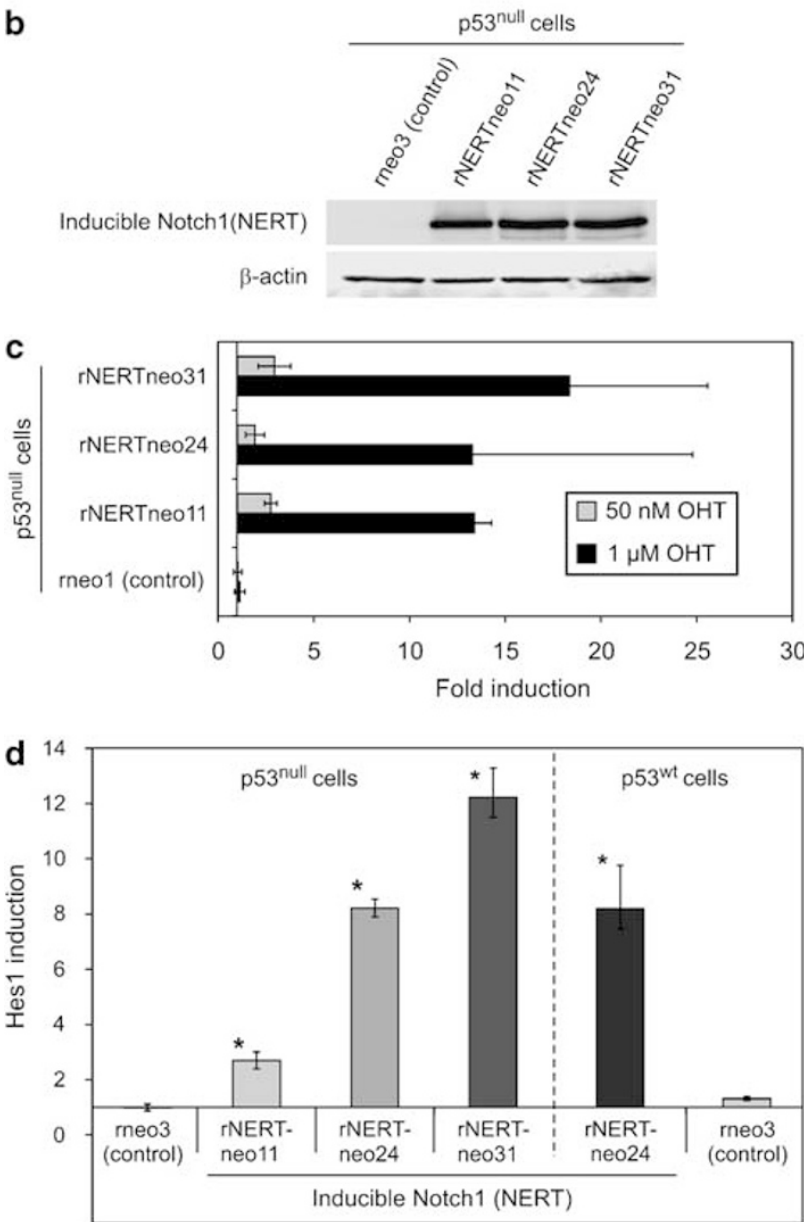

Figure 1 A Notch1 inducible system in p53 ${ }^{\text {null }}$ FDCP-mix cells. (a) p53 is functional in $p 53^{\text {wt }}$ FDCP-mix cells, but not in $p 53^{\text {null }}$ FDCP-mix cells. $p 53^{\text {wt }}$ and p53 ${ }^{\text {null }}$ FDCP-mix cells were treated with $\gamma$-radiation and cell lysates were prepared at indicated time points after irradiation. Western blots were performed using antip21 and anti- $\beta$-actin antibodies. (b) The NERT (inducible Notch1) protein is expressed in $p 53^{\text {null }}$ rNERTneo clones. $p 53^{\text {null }}$ FDCP-mix cells were stablytransfected with a retroviral vector carrying the NERT $\mathrm{CDNA}^{9}$ or an empty control vector (rneo). ${ }^{9}$ The correct-sized NERT proteins were detected by Western blotting with an antibody against the estrogen receptor (ERT) moiety. (c) Notch signaling is functional and inducible in $p 53^{\text {null }}$ cell clones expressing the NERT protein. Activation of Notch $1^{1 \mathrm{C}}$ was determined by transient transfection of rNERTneo and rneo control $p 53^{\text {null }}$ cells with a reporter plasmid carrying the luciferase gene under the control of 12 RBP-J binding sites. Cells were treated with either $50 \mathrm{nM}$ or $1 \mu \mathrm{M}$ $\mathrm{OHT}$ for $24 \mathrm{~h}$, and luciferase activity in cell lysates was determined. Mean induction values \pm S.E.M. corrected for transfection efficiency are shown, respectively. The experiment was repeated three times with virtually identical results. (d) Activated Notch1 induces Hes 1 expression in both $p 53^{\text {null }}$ and $p 53^{\text {wt }}$ FDCP-mix cells. FDCPmix cells were cultured in the presence or absence of $500 \mathrm{nM}$ OHT. Total RNA was harvested after $8 \mathrm{~h}$ and expression levels of Hes1 RNA were analyzed by real-time PCR. The experiment was repeated three times with virtually identical results. Hes1 is statistically and significantly upregulated in the presence of $\mathrm{OHT}\left({ }^{\star} P<0.01\right)$ 
clones used in this report (Figure 1c). Control rneo clones did not express the NERT protein and did not transactivate the RBP-J pathway regardless of the addition of OHT (Figure $1 \mathrm{~b}$ and $\mathrm{c}$ ). To confirm that the Notch1-signaling pathway is activated by the addition of OHT, we determined the expression of endogenous Notch1 target genes of the Hes and Hey family in response to OHT treatment. In NERTexpressing p53 null FDCP-mix cells, Hes1, and Hey1 expression was upregulated after the addition of OHT, whereas in control p53 ${ }^{\text {null }}$ FDCP-mix cells, the expression of Hes1 and Hey1 remained unaltered (Figure 1d and data not shown)

Reduction of proliferation by activated mNotch1 is dependent on p53. To evaluate if the reduction of proliferation of FDCP-mix cells by activated Notch1 is dependent on p53, cell numbers and $\left[{ }^{3} \mathrm{H}\right]$ thymidine incorporation into DNA of proliferating wild-type p53 (p53 ${ }^{\mathrm{wt}}$ ) and p53-deficient ( $p 53^{\text {null }}$ ) rNERTneo clones and control rneo clones, respectively, were measured in the presence and absence of OHT. Under conditions optimal for self-renewal and proliferation, that is, in the presence of high IL-3, cell numbers and $\left[{ }^{3} \mathrm{H}\right]$ thymidine incorporation of rNERTneo cells were virtually identical to that of rneo control cells, for either $p 53^{\mathrm{wt}}$ FDCP-mix cells or $\mathrm{p} 53^{\text {null }}$ FDCP-mix cells, respectively, although generally $p 53^{\text {null }}$ cells proliferated at $a$ higher rate as $\mathrm{p} 53^{\mathrm{wt}}$ cells (Figure $2 \mathrm{a}$ and data not shown). In contrast to the $\mathrm{p} 53^{\mathrm{wt}}$ cells, however, in which induction of Notch signaling by OHT significantly reduced the proliferation in a concentration-dependent manner, ${ }^{8}$ proliferation of $p 53^{\text {null }}$ cells was not altered by OHT-induced Notch signaling (Figure 2a and data not shown). Proliferation of control rneo $p 53^{\text {wt }}$ and $p 53^{\text {null }}$ FDCP-mix cells was unaffected by OHT (Figure 2a and data not shown).

Since with $\left[{ }^{3} \mathrm{H}\right]$ thymidine incorporation into DNA we can only determine the average proliferation of the whole population, we further assessed the kinetics of the activated Notch1-induced reduction in proliferation by carboxyfluorescein diacetate succinimidyl ester (CFSE) labeling. ${ }^{14}$ In contrast to DNA labels, all cells in contact with sufficient concentrations of CFSE will become labeled regardless of their stage in the cell cycle. When a CFSE-labeled cell divides, CSFE is apportionated equally between the two daughter cells. Provided that the initial cell labeling and protein distribution between daughter cells are equal, a number of peaks of progressively halving CFSE fluorescence is measured. By using this approach, we confirmed the reduction in proliferation induced by activated Notch1 (Figure 2b).

Expression of $\mathrm{p}^{5} 3^{\mathrm{wt}}$ restores reduction in proliferation by activated Notch1. To confirm that the reduction in cell proliferation is dependent on p53, and not caused by another unrelated mutation in the p53 $3^{\text {null }}$ FDCP-mix cells, we attempted to constitutively express $p 53^{\text {wt }}$ in $p 53^{\text {null }}$ FDCPmix cells using several different expression vectors, including a previously described pCAG-based ${ }^{15}$ p53 expression construct conferring Puromycin resistance to transfected cells. This proved to be difficult, because directly after reexpression of functional p53 ${ }^{\text {wt }}$ many cells died due to p53induced apoptosis on the one hand, and on the other hand
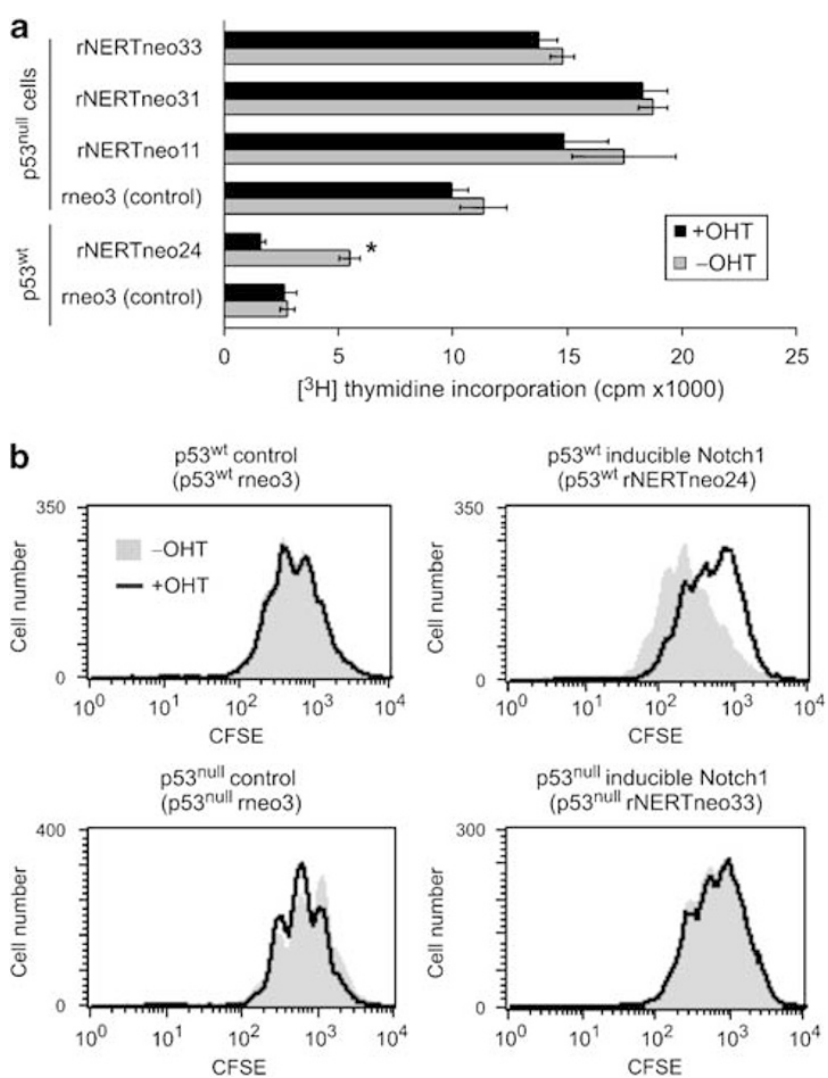

Figure 2 p53 is required for activated Notch $1^{1 \mathrm{C}}$-induced reduction in proliferation. To analyze the influence of activated Notch1 on the proliferation rate of $p 53^{\text {wt }}$ and $p 53^{\text {null }}$ FDCP-mix cells, rNERTneo cell clones were cultured under self-renewal conditions in the absence or presence of $500 \mathrm{nM} \mathrm{OHT}$. (a) Cells were plated at $6 \times 10^{4}$ per $\mathrm{ml}$ in self-renewal conditions and cultured in the presence or absence of $\mathrm{OHT}$ for $24 \mathrm{~h}$. $\left[{ }^{3} \mathrm{H}\right]$ thymidine incorporation was measured in triplicate cultures as described in Material and Methods. The experiment was repeated four times with virtually identical results. Statistically significant reduction of proliferation was only observed in $p 53^{\text {wt }}$ rNERTneo24 cells ( ${ }^{\star} P<0.001$ ). (b) Cells were labeled with CFSE at a concentration of $5 \mu \mathrm{M}$ and CFSE intensity was measured after 3 days by FACS analysis. A representative example for each cell line is shown, respectively. The experiment was repeated two times with virtually identical results

the remaining living cell cultures lost functional p53 activity either due to the presence of spontaneous Puromycin resistant $p 53^{\text {null }}$ cells that have a proliferative advantage because of their more rapid proliferation or due to mutations that lead to loss of p53 activity (data not shown). Nevertheless, we succeeded in achieving transient expression of functional $\mathrm{p} 53^{\mathrm{wt}}$ in $\mathrm{p} 53^{\text {null }}$ FDCP-mix cells for up to 3 weeks (Figure $3 a$ and $b$ ). Transfected p53 ${ }^{\text {null }}$ NERT FDCP-mix cell cultures, which expressed $p 53^{\text {wt }}$ were then tested for the inhibition of proliferation by activated Notch. As shown in Figure $3 c$ and d, re-expression of $p 53^{\text {wt }}$ restored the reduction of proliferation of $p 53^{\text {null }}$ NERT FDCP-mix cells by $\mathrm{OHT}$-induced Notch signalling, while proliferation of control pCAG vector-transfected cells was not affected by OHT.

Activated Notch upregulates p21 expression in dependence of p53. p21 $1^{\mathrm{WAF} / \mathrm{Cip}}$ was originally identified as a downstream mediator of p53-induced growth arrest. ${ }^{16,17}$ In addition, in keratinocytes, in which Notch signaling also induces growth arrest and differentiation, induction of p21 
a

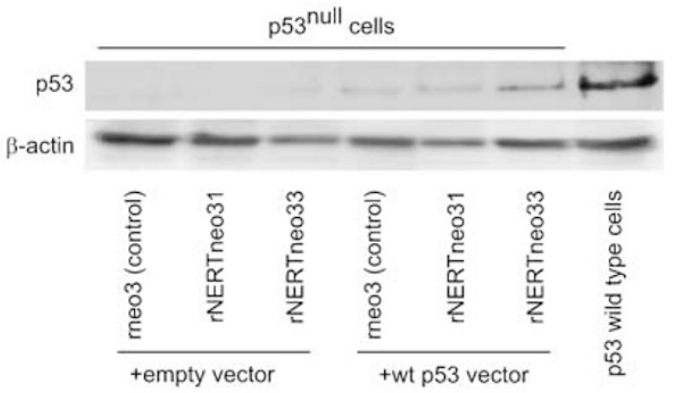

C
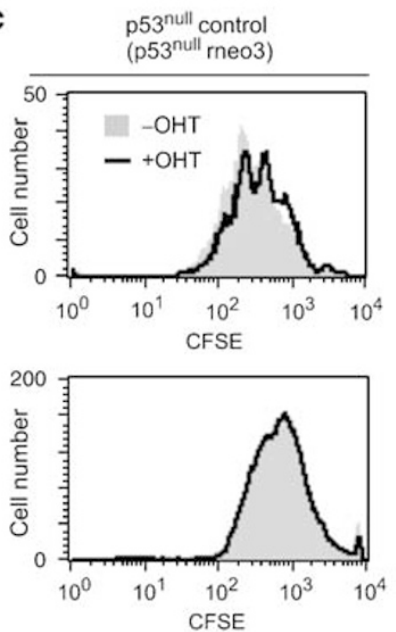
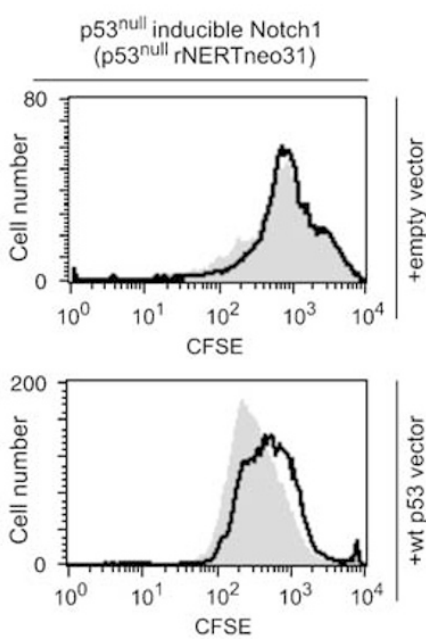

b

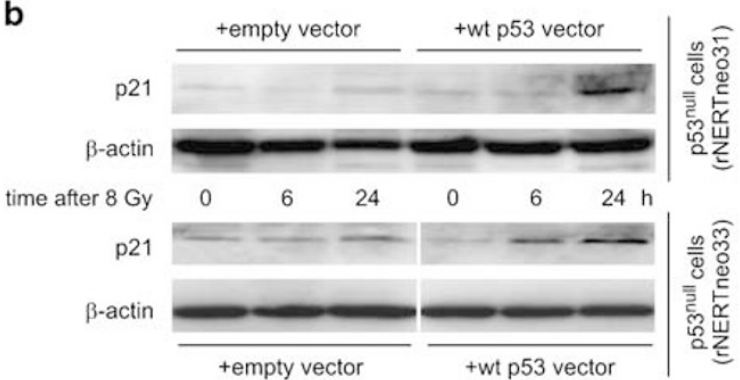

d

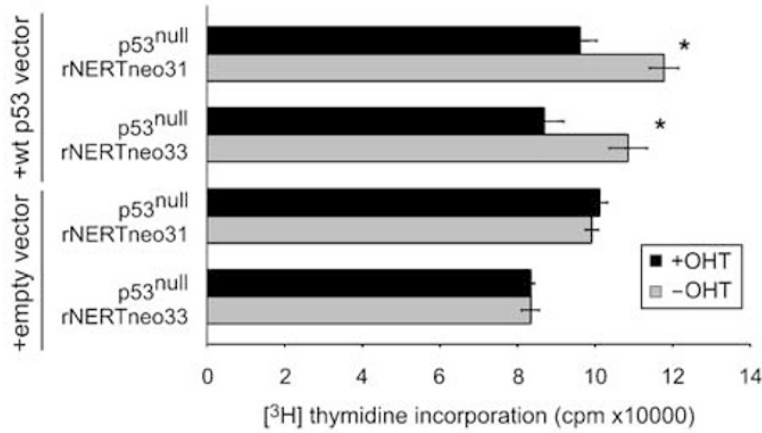

$\left[{ }^{3} \mathrm{H}\right]$ thymidine incorporation $(\mathrm{cpm} \times 10000)$

Figure 3 Reconstitution of the $p 53$ status in $p 53^{\text {null }}$ cells restores Notch1-induced reduction in proliferation. $p 53^{\text {null }}$ FDCP-mix cells were transfected with a p53 $3^{\text {wt }}$ expressing vector (pCAG-wt p53) or an empty control vector. (a) Expression of p53 ${ }^{\text {wt }}$ protein in transfected p53 $3^{\text {null }}$ FDCP-mix cells. The correct-sized p53 proteins were detected by Western Blotting with an antibody against p53. (b) Expression of $p 53^{\text {wt }}$ protein in transfected $p 53^{\text {null }}$ FDCP-mix cells restores p21 upregulation after $\gamma$-radiation. Transfected cells were treated with eight gray $\gamma$-radiation and cell lysates were prepared at indicated time points after irradiation. Western blots were performed using anti-p21 and anti- $\beta$-actin antibodies. (c) Transfected cells in selection with puromycin were labeled with CFSE at a concentration of $5 \mu \mathrm{M}$ and CFSE intensity was measured after 3 days by FACS analysis. A representative example for each cell line is shown, respectively. The experiment was repeated three times with virtually identical results. (d) FDCPmix p53 $3^{\text {null }}$ cells were transfected with a p53 $3^{\text {wt }}$ expressing vector (pCAG-wt p53) and puromycin-resistant cells were analyzed 3 weeks after transfection. Cells were plated in self-renewal conditions at $1 \times 10^{5} \mathrm{ml}$ and cultured in the presence or absence of $500 \mathrm{nM} \mathrm{OHT}$ for $48 \mathrm{~h}$. $\left[{ }^{3} \mathrm{H}\right]$ thymidine incorporation was measured in triplicate cultures as described in Material and Methods. The experiment was repeated two times with virtually identical results. Reduction in the proliferation rate is significant for both $\mathrm{p} 53^{\mathrm{wt}}$ vector expressing rNERTneo $p 53^{\text {null }}$ cells $\left({ }^{*} P<0.001\right)$

expression by activated Notch was described. ${ }^{18}$ Thus, a possible underlying mechanism for the Notch1-induced, p53dependent, cell cycle arrest could be that Notch1 upregulates p21 expression in a p53-dependent manner. First, we determined the protein levels of p21 in p53 ${ }^{\mathrm{wt}}$ and $p 53^{\text {null }}$ NERTneo and rneo FDCP-mix clones in the presence or absence of $\mathrm{OHT}$. After addition of $\mathrm{OHT}$, p21 protein expression rapidly increased in $p 53^{\text {wt }}$ NERTneo FDCP-mix cells, but not in p53 ${ }^{\text {null }}$ NERTneo FDCP-mix cells (Figure 4a). In control p53 ${ }^{\text {wt }}$ and $\mathrm{p} 53^{\text {null }}$ rneo FDCP-mix cells, the p21 protein levels remained unchanged by the addition of OHT (Figure 4a). Thus, Notch signaling upregulates p21 expression only in $\mathrm{p} 53^{\mathrm{wt}}$ cells. Nucleotide sequence analysis indicated that the promoter region of p21 contains two p53 binding site and one canonical RBP-J binding site (Figure 5a). To test whether activation of Notch1 signaling could induce the p21 promoter and further, whether this induction would require the presence of $p 53^{\mathrm{wt}}$, we determined the transactivation of the p21 promoter containing the p53 and RBP-J-binding sites in p53 ${ }^{\mathrm{wt}}$ rNERTneo and $p 53^{\text {null }}$ rNERTneo FDCP-mix cells, respectively, in the presence or absence of $\mathrm{OHT}$. In the absence of $\mathrm{OHT}$, no transactivation of the p21 promoter in either $p 53^{\text {wt }}$ or $p 53^{\text {null }}$ rNERTneo FDCP-mix cells was observed. After the addition of OHT, the p21 promoter was only induced in $p 53^{\mathrm{wt}}$ cells but not in $\mathrm{p} 53^{\text {null }}$ rNERTneo FDCP-mix cells (Figure $4 \mathrm{~b}$ ).

The $2.4 \mathrm{~kb}$ region of the $\mathrm{p} 21$ promoter contains a sequence that fully matches the consensus binding site of RBP- $J^{19}$ and two conserved $\mathrm{p} 53$ binding sites. ${ }^{17}$ To test whether activated Notch1 transactivates the p21 promoter via the canonical RBP-J-binding site, luciferase reporter constructs containing either the functional RBP-J binding site of the $\mathrm{p} 21$ promoter or a mutated sequence (Figure 5a) that does not bind RBP-J $\mathrm{J}^{19}$ were transiently transfected into $053^{\text {wt }}$ rNERTneo and rneo FDCP-mix cells and luciferase activity was determined in the presence or absence of OHT. Induction of Notch signaling by the addition of $\mathrm{OHT}$ resulted in the transactivation of the construct containing the canonical RBP-J binding site after induction (Figure 5b). Addition of $\mathrm{OHT}$ to control rneo FDCPmix cells did not activate transcription (Figure $5 b$ ). Unexpectedly, the mutant p21RBP-Jmut promoter compromised in 

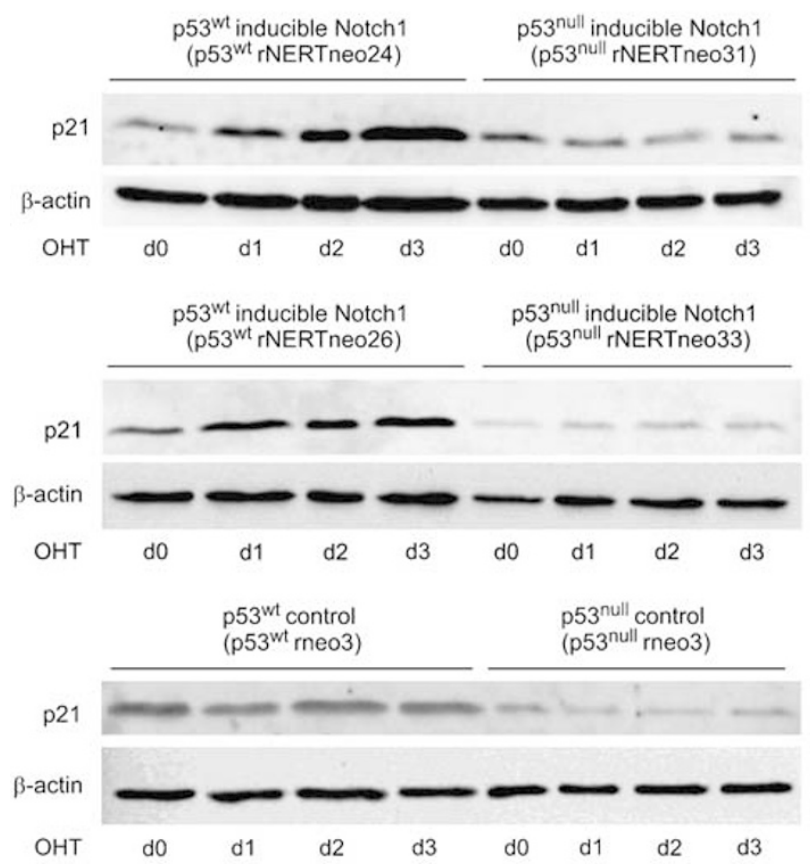

b

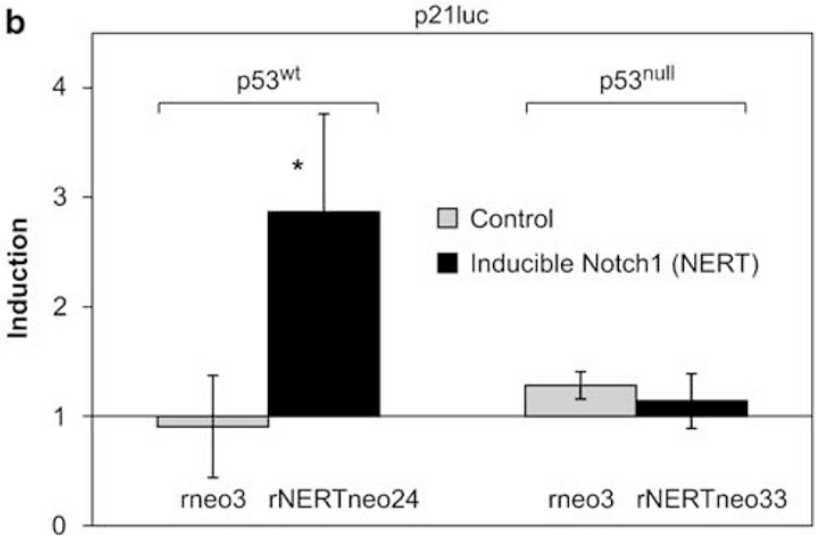

C



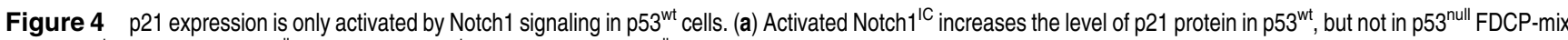
cells. $p 53^{\text {wt }}$ rneo control, p53 $3^{\text {null }}$ rneo control, p53 ${ }^{\text {wt }}$ rNERTneo and p53 $3^{\text {null }}$ rNERTneo clones were treated with $500 \mathrm{nM}$ OHT for up to 3 days (three independent experiments). Cell lysates were prepared at indicated time points after induction. Western blots were carried out using antibodies against p21 and actin. A representative Western blot analysis is shown. (b) Activated Notch1 induces p21 promoter activity in p53 ${ }^{\text {wt }}$ FDCP-mix cells, but not in p53 ${ }^{\text {null }}$ FDCP-mix cells. p53 ${ }^{\text {wt }}$ rneo control, p53 $3^{\text {null }}$ meo control, p53 $3^{\text {wt }}$ rNERTneo and $p 53^{\text {null }}$ rNERTneo clones were transiently transfected in triplicates with a reporter plasmid (p21luc) carrying a luciferase gene under the control of a $2.3 \mathrm{~kb}$ fragment of the p21 promoter shown in Figure 5a. Cells were cultured under self-renewal conditions in the absence or presence of $250 \mathrm{nM} \mathrm{OHT}$ for $16 \mathrm{~h}$, and luciferase activity was measured and normalized to the activity of renilla luciferase. The means \pm S.D. corrected for transfection efficiency are shown. The experiment was repeated three times with virtually identical results. Statistically significant upregulation of p21 promoter activity was only observed in p53 ${ }^{\text {wt }}$ rNERTneo24 cells $\left({ }^{*} P<0.02\right)$. (c) Activated Notch1 induces MDM2 promoter activity in p53 ${ }^{\text {wt }}$ FDCP-mix cells, but not in p53 ${ }^{\text {null }}$ FDCP-mix cells. p53 ${ }^{\text {wt }}$ rneo control, p53 $3^{\text {null }}$ rneo control, p53 ${ }^{\text {wt }}$ rNERTneo and p53 ${ }^{\text {null }}$ rNERTneo clones were transiently transfected in triplicates with a reporter plasmid (mdm2luc) carrying a luciferase gene under the control of a $0.4 \mathrm{~kb}$ fragment of the mdm2 promoter. Cells were cultured under self-renewal conditions in the absence or presence of $250 \mathrm{nM} \mathrm{OHT}$ for $16 \mathrm{~h}$, and luciferase activity was measured and normalized to the activity of renilla luciferase. The means \pm S.D. corrected for transfection efficiency are shown. The experiment was repeated three times with virtually identical results. Statistically significant upregulation of p21 promoter activity was only observed in p53 ${ }^{\text {wt }}$ rNERTneo24 cells $\left({ }^{*} P<0.001\right.$ )

RBP-J binding was transactivated by induction of Notch1 signaling to a similar extent as the construct containing the canonical RBP-J binding site (Figure $5 \mathrm{~b}$ ). These data suggest that the canonical RBP-J site is not involved in mediating the Notch1-dependent transactivation of the p21 promoter. Next, we tested whether the transactivation of the p21 promoter by activated Notch1 would depend on the p53 binding sites. As shown in Figure $5 c$, deletion of either one of the p53 binding site led to a reduction in Notch1-dependent transactivation of the p21 promoter and deletion of both p53 binding sites completely abolished Notch1-induced transactivation of the p21 promoter. In line with these results, activated Notch1 also transactivated the mdm2 promoter, which does contain two p53 binding sites but no canonical RBP-J binding site (Figure 4c).

To test whether activated Notch would enhance binding of p53 to the endogenous promoter, chromatin preparations from $\mathrm{p53} 3^{\mathrm{wt}}$ rNERTneo FDCP-mix cells in the presence or absence of OHT were crosslinked to cellular DNA and immunoprecipitated with anti-p53 antibodies, followed by PCR amplifications of specific p21 promoter regions. As shown in Figure 6, the two fragments of the mouse p21 promoter containing the $\mathrm{p} 53$ binding sites, in particular binding site 2, were of higher abundance in the immunoprecipitates from rNERTneo FDCP-mix cells treated with OHT compared to $\mathrm{rNERTneo} \mathrm{FDCP-mix} \mathrm{cells} \mathrm{kept} \mathrm{without} \mathrm{OHT.} \mathrm{As} \mathrm{expected,}$ no difference was observed after OHT treatment in the amount of immunoprecipitated fragments of a p21 promoter proximal control region that does not harbor p53 binding sites (Figure 6). These results were also confirmed by real-time PCR (data not shown). Taken together, these results provide evidence that Notch-signaling upregulates p21 expression by a p53-dependent mechanism involving enhanced binding of p53 to the p21 promoter. 
Activated Notch promotes myeloid and erythroid differentiation independently of p53. Recently, we have shown that activated Notch1 induced myeloid and erythroid differentiation in $p 53^{\mathrm{wt}}$ rNERTneo FDCP-mix cells. ${ }^{8,20}$ Therefore, we asked whether differentiation into myeloid and erythroid cells by the induction of activated Notch1 was similarly accelerated in $\mathrm{p5} 3^{\text {null }}$ rNERTneo FDCP-mix cells in the presence of lineage-affiliated cytokines. In the presence of GM-CSF and G-CSF (myeloid differentiation conditions) differentiation is directed along the myeloid lineage and in the presence of erythropoietin and low amounts of IL-3 along the erythroid lineage. Thus, p53 null $r$ NERTneo FDCP-mix cells, p53 ${ }^{\text {wt }}$ rNERTneo FDCP-mix cells, p53 ${ }^{\text {null }}$ control rneo FDCPmix cells and $p 53^{\mathrm{wt}}$ control rneo FDCP-mix cells were cultured under conditions that promote either myeloid differentiation or erythroid differentiation in the presence or absence of OHT and were monitored for changes in morphology and cell surface phenotype. As shown recently for p53 $^{\text {wt }}$ rNERTneo FDCP-mix cells, ${ }^{8,20}$ differentiation along the myeloid as well as erythroid lineages was accelerated in
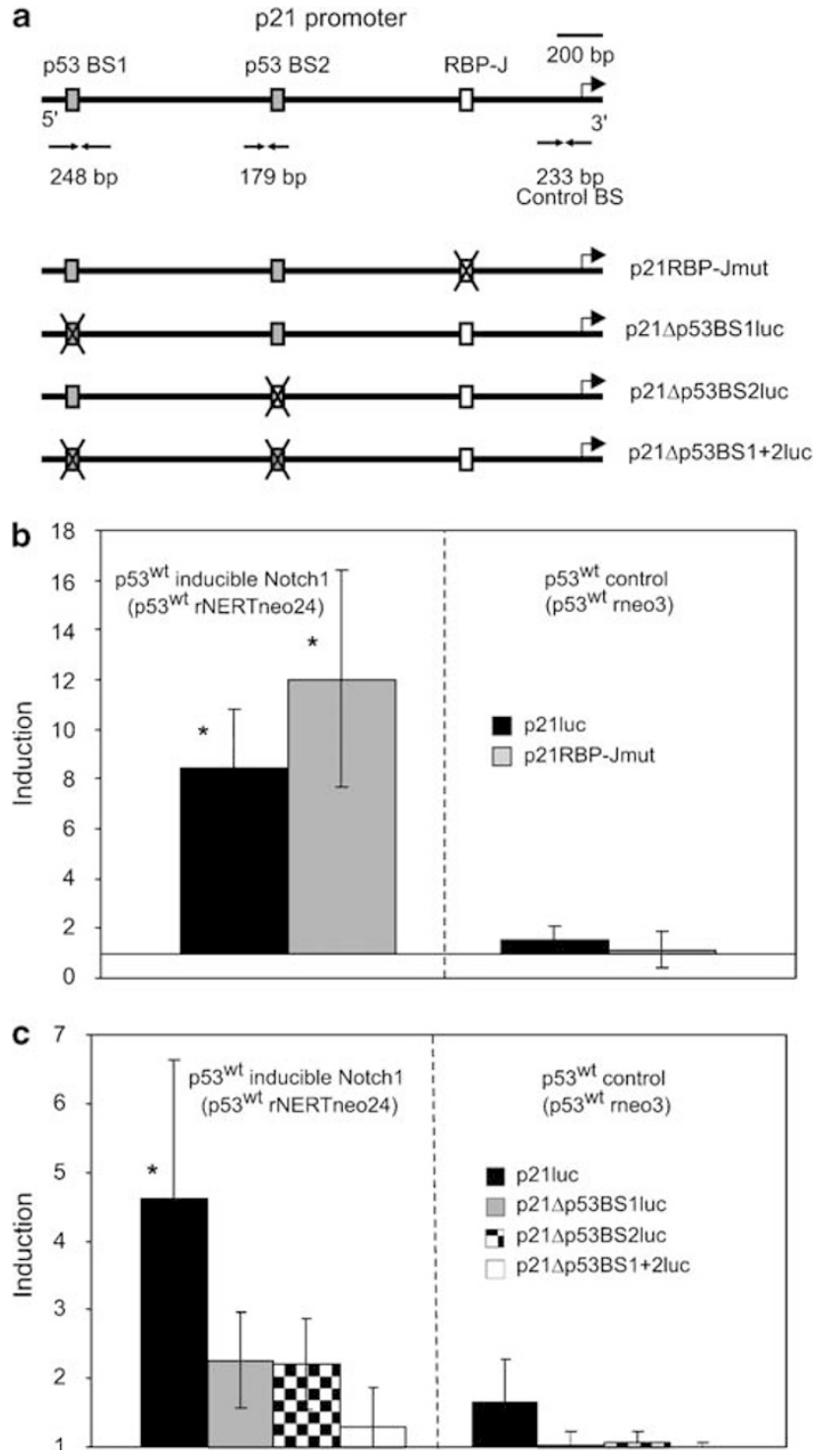

the p53 ${ }^{\text {null }}$ rNERTneo FDCP-mix cells (Tables 1 and 2). Differentiation of $\mathrm{p} 53^{\mathrm{wt}}$ and $\mathrm{p} 53^{\text {null }}$ rneo control cells was unaltered by the addition of OHT (Tables 1 and 2). Since activated Notch1 accelerated myeloid and erythroid differentiation in both $\mathrm{p} 53^{\mathrm{wt}}$ and $\mathrm{p} 53^{\text {null }}$ rNERTneo FDCPmix cells, we analyzed whether activated Notch1 alters proliferation in differentiation conditions. While the activation of Notch1-signaling considerably reduced proliferation of p53 ${ }^{\text {wt }}$ rNERTneo FDCP-mix cells (Table 3 ) in differentiation conditions, ${ }^{8}$ Notch1 signaling did not alter proliferation during the first 4 days in differentiation medium in $p 53^{\text {null }}$ cells (Table 3). Only with the appearance of terminally differentiated cells, proliferation also started to decrease in p53 ${ }^{\text {null }}$ rNERTneo FDCP-mix cells to a similar extent as in p53 ${ }^{\text {null }}$ rneo FDCP-mix cells (data not shown). Taken together, our data show that activated Notch1 promotes differentiation of $p 53^{\mathrm{wt}}$ and $\mathrm{p} 53^{\text {null }}$ FDCP-mix cells along the myeloid and erythroid lineages, but activated Notch1 reduces cell proliferation only in $553^{\text {wt }}$ FDCP-mix cells and not in p53 ${ }^{\text {null }}$ FDCP-mix cells.

\section{Discussion}

In the present work, we provide evidence that p53 is a critical determinant for Notch-mediated inhibition of proliferation: depending on the presence of functional p53, proliferation of multipotent hematopoietic progenitor cells is inhibited by activated Notch1. Recently, we showed that this inhibition of proliferation is related to $a G_{0} / G_{1}$ cell cycle arrest. ${ }^{7}$ Induction of p21 expression is one of the earliest cell cycle regulatory

Figure 5 Activated Notch1 induces p21 promoter activity in p53 ${ }^{\text {wt }}$ FDCP-mix cells in a p53-dependent manner. (a) The diagram shows the schematic p21 promoter used in this study with the known p53 binding sites and the consensus binding site for RBP-J. Amplicons for investigation of these sites and a control binding site in the ChIP assay (see Figure 6) are indicated by head to head arrows. Below are the luciferase constructs used in this assay: p21RBP-Jmut contains the p21 promoter with a mutated and non-functional RBP-J-binding site. The other plasmids used lack either the first p53 binding site (p21 1 p53BS1luc), the second p53 binding site ( $\mathrm{p} 21 \Delta \mathrm{p} 53 \mathrm{BS} 2 \mathrm{luc}$ ) or both p53 binding sites (p21 $\mathrm{p} 53 \mathrm{BS} 1+2 \mathrm{luc}$ ) of the p21 promoter. (b) Induction of the p21 promoter by activated Notch1 is not dependent on binding of RBP-J. The $p 53^{\text {wt }}$ control clone rneo3 and the $p 53^{\text {wt }}$ clone rNERTne024 were transiently transfected in triplicates with a reporter plasmid carrying a luciferase gene either under the control of the p21 promoter (p21luc) or under a p21 promoter lacking a functional RBP-J binding site (p21RBP-Jmut). Cells were cultured under self-renewal conditions in the absence or presence of $250 \mathrm{nM}$ $\mathrm{OHT}$ for $16 \mathrm{~h}$, and luciferase activity was measured and normalized to the activity of renilla luciferase. The means \pm S.D. corrected for transfection efficiency are shown. The experiment was repeated three times with virtually identical results. Statistically significant upregulation (asterisk) of p21 promoter activity was observed in p53 $3^{\text {wt }}$ rNERTneo24 cells for both reporter constructs $\left({ }^{\star} P<0.02\right)$. (c) Induction of the p21 promoter by activated Notch1 is dependent on binding of $p 53$. The $p 53^{\text {wt }}$ control clone rneo3 and the $\mathrm{p} 53^{\mathrm{wt}}$ clone rNERTneo24 were transiently transfected in triplicates with a reporter plasmid carrying a luciferase gene under the control of the p21 promoter (p21luc) or a luciferase gene under the control of a p21 promoter lacking either the first $\mathrm{p} 53$ binding site (p21 $\Delta \mathrm{p} 53 \mathrm{BS} 1 \mathrm{luc}$ ), the second $\mathrm{p} 53$ binding site (p21 p53BS2luc) or both p53 binding sites (p21 pp53BS1 + 2luc). The cells were cultured under self-renewal conditions in the absence or presence of $250 \mathrm{nM}$ $\mathrm{OHT}$ for $16 \mathrm{~h}$, and luciferase activity was measured and normalized to the activity of renilla luciferase. The means \pm S.D. corrected for transfection efficiency are shown. The experiment was repeated three times with virtually identical results. Statistically significant upregulation of p21 promoter activity was only observed in $p 53^{\mathrm{wt}}$ rNERTneo24 cells for the construct p21luc $\left({ }^{*} P<0.02\right)$ 

p53 $3^{\text {wt }}$ inducible Notch1 (p53 ${ }^{\text {wt }}$ rNERTneo24)

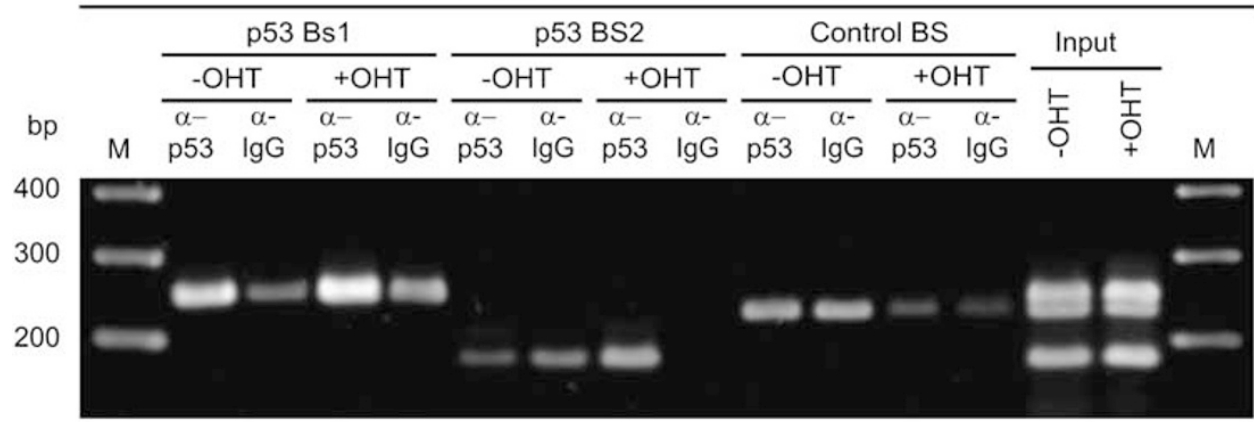

b

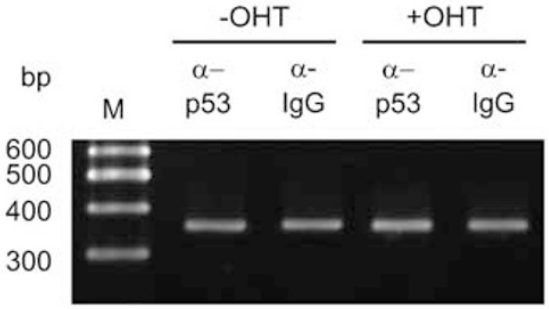

C

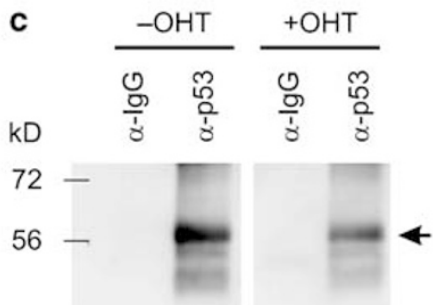

Figure 6 Notch1 signaling induces increased binding of the p53 protein to the endogenous p21 promoter. p53 ${ }^{\text {wt }}$ rNERTneo24 cells were cultured under self-renewal conditions in the presence or absence of $500 \mathrm{nM} \mathrm{OHT}$ for $8 \mathrm{~h}$. ChIP assays were performed as described in Material and Methods with antibodies specific for p53 or nonimmune $\lg$ G control followed by PCR amplifications of the p53 binding site 1 (BS1) and 2 (BS2) and an additional control binding site (no p53 binding) of the p21 promoter as indicated in Figure 5a. (a) Analysis of the BS1, BS2 and control binding site by semi-quantitative PCR. Additionally, $0.8 \%$ input DNA was analyzed in the multiplex reaction for all three-primer pairs. (b) Even DNA recovery of the different immunoprecipitated DNAs. Recovery was checked by spiking samples with external pUC18 DNA and semiquantitative PCR. (c) p53 protein could be detected in the immunoprecipitated fractions. 1/12th of the beads bound fraction was analyzed by Western blotting with an antibody against $\mathrm{p} 53$

Table 1 Activated Notch $1^{1 \mathrm{C}}$ accelerates myeloid differentiation of $p 53^{\text {null }}$ cells

\begin{tabular}{lcccr}
\hline & & \multicolumn{3}{c}{$\%$ of cells after $\mathbf{4}$ days } \\
\cline { 3 - 5 } p53 $^{\text {null }}$ clone & $\begin{array}{c}\text { Culture } \\
\text { conditions }\end{array}$ & BI & EG & LG \\
& -OHT & 94 & 4 & 2 \\
rneo1 & +OHT & 91 & 5 & 4 \\
rNERTneo11 & -OHT & 94 & 2 & 4 \\
rNERTneo24 & +OHT & 78 & 5 & 17 \\
& -OHT & 91 & 5 & 4 \\
rNERTneo25 & +OHT & 65 & 12 & 23 \\
& -OHT & 96 & 4 & 0 \\
rNERTneo31 & +OHT & 79 & 11 & 10 \\
& -OHT & 95 & 5 & 0 \\
& +OHT & 37 & 23 & 40 \\
\hline
\end{tabular}

Cells were cultured under cytokine conditions that promote myeloid differentiation with or without $1 \mu \mathrm{M}$ OHT. Differentiation of the cultures was followed by scoring the morphology of May-Grünwald-Giemsa stained cytospin preparations of the cells. BI, undifferentiated blasts; EG, early granulocytes (promyelocytes and myelocytes); LG, late granulocytes (metamyelocytes and segmented neutrophils). Data from a representative experiment are shown. The experiment was repeated two times with virtually identical results. The increase in myeloid differentiation by activated Notch ${ }^{1 \mathrm{C}}$ is statistically significant for all rNERTneo clones analyzed (clones $11,24,25$, and $31, P<0.001$ )

events underlying growth arrest. We have shown here that Notch1 signaling upregulates p21 expression. This upregulation required the presence of p53. Because p53 can also cause cell cycle arrest by transcriptionally upregulating p21, ${ }^{21}$ one possibility could be that activated Notch1 upregulates p53 expression. In several mammalian cell lines including human hepatocellular carcinoma cells, mouse neural progenitor cells,
Table 2 Activated Notch $1^{1 \mathrm{C}}$ accelerates erythroid differentiation of $\mathrm{p} 53^{\text {null }}$ cells

\begin{tabular}{lcc}
\hline p53 $^{\text {null }}$ clone & Culture conditions & Ter119+ $^{+}$cells (\%) \\
\hline rneo 3 & -OHT & 22 \\
rNERTneo11 & +OHT & 21 \\
rNERTneo33 & -OHT & 27 \\
& +OHT & 39 \\
& -OHT & 20 \\
& +OHT & 25 \\
\hline
\end{tabular}

Cells were cultured under cytokine conditions that promote erythroid differentiation with or without $1 \mu \mathrm{M}$ OHT. Differentiation of the cultures was followed by FACS analyses of living cells using an antibody against Ter119. Data from a representative experiment are shown. The experiment was repeated two times with virtually identical results. The increase in erythroid differentiation by activated Notch ${ }^{\mathrm{C}}$ is statistically significant for all rNERTneo clones analyzed (clones 11 and $33, P<0.001$ )

and human cervical cancer cells, expression of activated Notch $1^{\text {IC }}$ elevated the levels of nuclear p53 and its target gene transcription. ${ }^{22-24}$ In addition, two well known direct Notch target genes, Hes1 and Hey1, upregulate p53 activity through repression of HDM2 transcription. ${ }^{5}$ However, since we did not see an upregulation of $\mathrm{p} 53 \mathrm{mRNA}$ and protein in $\mathrm{p} 53^{\mathrm{wt}} \mathrm{FDCP}$ mix cells after activation of Notch signaling (data not shown), it seems unlikely that the Notch1-induced proliferation arrest is mediated by an upregulation of $\mathrm{p} 53$ expression.

The p21 promoter used in this study contains two $\mathrm{p} 53^{17}$ and one RBP-J binding site. Although binding of the RBP-J protein to this RBP-J site as well as an involvement of RBP-J in Notch-dependent transactivation was recently shown in keratinocytes, $^{18}$ transactivation of the p21 promoter by 
Table 3 Activated Notch $1^{1 \mathrm{C}}$ does not affect proliferation of $p 53^{\text {null }}$ cells in differentiation conditions

\begin{tabular}{lcc}
\hline & \multicolumn{2}{c}{ Cell number $\times \mathbf{1 0}^{\mathbf{5}}$} \\
\cline { 2 - 3 } Cell clone & $-\mathbf{O H T}$ & $\mathbf{+ O H T}$ \\
\hline$p 53^{\text {null }}$ & & \\
rneo1 & $1.8 \pm 0.3$ & $1.7 \pm 0.4$ \\
rNERTneo11 & $1.6 \pm 0.3$ & $1.9 \pm 0.4$ \\
rNERTneo24 & $1.5 \pm 0.3$ & $1.2 \pm 0.4$ \\
rNERTneo25 & $1.6 \pm 0.3$ & $1.6 \pm 0.4$ \\
rNERTneo31 & $1.5 \pm 0.3$ & $1.2 \pm 0.4$ \\
p53t & & \\
A7rneo1 & $1.3 \pm 0.4$ & $1.2 \pm 0.3$ \\
A7rNERTneo24 & $1.3 \pm 0.3$ & $0.6 \pm 0.2$ \\
A7rNERTneo25 & $0.7 \pm 0$ & $0.1 \pm 0$ \\
A7rNERTne026 & $1.2 \pm 0.4$ & $0.4 \pm 0.1$ \\
\hline
\end{tabular}

$\mathrm{p} 53^{\text {null }}$ and $\mathrm{p} 53^{\mathrm{wt}}$ FDCP-mix cells were cultured under cytokine conditions that promote myeloid differentiation with or without $1 \mu \mathrm{M}$ OHT. Cell numbers were determined after 3 days ( $p 53^{\text {wt }}$ cells) or 4 days ( $553^{\text {null }}$ cells). Data from a representative experiment are shown. The experiment was repeated two times with virtually identical results. The reduction in proliferation is statistically significant for $\mathrm{p} 53^{\mathrm{wt}} \mathrm{A}$ 7rNERTneo cells (all p $53^{\mathrm{wt}}$ A7rNERTneo clones analyzed (clones 24, 25 and 26, $P<0.001$ ) but not for p53 $3^{\text {null }}$ rNERTneo cells. The sligh reduction of cell numbers in $p 53^{\text {null }}$ rNERTneo24 and $p 53^{\text {null }}$ rNERTneo31 clones results from terminally differentiated cells in the presence of OHT (compare Table 1)

activated Notch was not mediated via this RBP-J-binding site in hematopoietic progenitor cells. A recent report has indicated that Notch activity on RBP-J-responsive promoters critically depends on protein modules and promoter context. ${ }^{25}$ Thus, one possibility to explain this discrepancy could be that activated Notch1 transactivates the p21 promoter via the RBP-J binding site in keratinocytes, but not in hematopoietic progenitor cells due to the lack of other essential cofactors in hematopoietic cells.

In addition to the RBP-J-dependent mechanism, Mammucari et al. ${ }^{26}$ identified a second Calcineurin-dependent mechanism for transactivation of p21 by activated Notch1 in keratinocyte growth and differentiation control, acting on the p21 TATA box proximal region. While transactivation of the p21 promoter by increased Calcineurin/NFAT activity induced by Notch signaling required RBP-J and implies a crosstalk between these two signaling pathways, we show here a novel, RBP-J independent mechanism for transactivation of the p21 promoter by activated Notch1 that critically depends on the p53 binding sites of the p21 promoter. Deletion of both p53 binding sites of the p21 promoter completely abolished transactivation, suggesting that p53 is required for Notch1-mediated transactivation of p21. The activated Notch1-induced, increased binding of p53 to these sites further suggests that enhanced binding of p53 to the p21 promoter after activation of Notch1 signaling is involved in the activation of p21 transcription, thereby inducing a cell cycle arrest.

Post-translational modifications of the p53 protein enhance the ability of $p 53$ to activate transcription. ${ }^{27}$ Phosphorylation of $p 53$ at various sites can lead to either stabilization of p53, activation of $\mathrm{p} 53$ activity or recruitment of $\mathrm{CBP} / \mathrm{p} 300$ or $\mathrm{PCAF}$ and p53 acetylation. p53 acetylation can be involved in enhancing p53 DNA binding, activating p53 transcriptional activities and in p53 stabilization. Furthermore, specific combinations of post-transcriptional modifications generate distinct p53 cassettes that direct p53 towards precise cellular functions. ${ }^{28}$ While acetylation at $\mathrm{K} 320$ suppresses the apoptotic program and activates promoters such as p21 leading to a temporary cell cycle arrest, acetylation at K373 together with phosphorylation at S46 and S15 stabilizes the interaction with p300 and activates promoters of proapoptotic genes. ${ }^{28}$ Recently, it was shown that Notch1 interacts with p53 and inhibits its phosphorylation at S15 and $S 46^{29}$ sites which were implicated in the study by Knights et $a l^{28}$ in directing p53 to promoters for proapoptotic genes thereby activating the proapoptotic program. In line with the lack of p53 modifications, ${ }^{28}$ activated Notch1-inhibited p53-dependent transactivation and suppressed p53-dependent apoptosis of human colon cancer cells. ${ }^{29}$ In addition, several other reports have indicated that Notch signaling may negatively regulate p53 function and inhibit apoptosis. ${ }^{30-32}$ These data seem to be in contrast to other studies ${ }^{18,22-24}$ and our data shown here and previously ${ }^{7,8}$ that activated Notch1 reduces proliferation of hematopoietic progenitor cells through a p53-dependent pathway by blocking the cell cycle in $G_{0} / G_{1}$ but does not influence apoptosis. However, Notch effects as well as p53 modifications depend largely on the cell type, and considering the direct interaction of Notch with p53, it is tempting to speculate, that activated Notch may increase levels of p53 acetylated at $\mathrm{K} 320$, thereby blocking the cell cycle via p21.

Irrespective of the presence or absence of p53, Notch1signaling promoted myeloid and erythroid differentiation of FDCP-mix cells as described previously. ${ }^{8,20}$ This suggests that the Notch1-induced cell-cycle block and the induction of differentiation are unlinked events and most likely mediated by distinct biochemical mechanisms. Consistent with its function in temporarily halting the cell cycle under stress conditions, mice with a deficiency in p53 as well as mice with a deficiency in p21 have increased numbers of cycling hematopoietic stem cells under stress conditions, while hematopoietic differentiation is entirely normal. ${ }^{33-35}$ Thus, activated Notch1 may reduce proliferation in dependence of p53 via p21 upregulation, however, the induction of myeloid and erythroid differentiation by increased Notch1-signaling occurs by a different p53-independent pathway. Recently, we have shown that activated Notch1 directly and specifically upregulates the hematopoietic transcription factor PU.1 in correlation with its induction of myeloid differentiation. ${ }^{8}$ Along this line, we have identified $\beta$-globin as a direct Notch1 target gene involved in erythroid maturation. ${ }^{20}$ This suggests that the induction of differentiation by Notch1 signaling involves hematopoietic transcription factors as well as functional proteins but not cell cycle regulators. The role of Notch signaling for self renewal, maintenance, and proliferation of adult hematopoietic stem and progenitor cells is controversial. ${ }^{1}$ This may reflect the fact that the hematopoietic stem and progenitor compartment consists of several diverse cell types with different molecular signatures that are likely to respond in a different way to Notch signals. In the present study, we have used the multipotent cell line FDCP-mix that, although being an immortal cell line, shares many characteristics with primary common myeloid progenitor cells. It will be of considerable interest to determine, which of the hematopoietic stem and progenitor cell types respond in a similar way to Notch and p53 signaling 
as the FDCP-mix cells. In line with our work with FDCP-mix cells, Notch-signaling triggers two distinct pathways in keratinocytes, involving a p21 and a RBP-J independent mechanism, respectively, leading to growth arrest and differentiation. ${ }^{18}$ It remains to be tested whether p53 plays also a role for the Notch-induced growth arrest in keratinocytes.

\section{Materials and Methods}

Cell culture. FDCP-mix cells were maintained (self renewal conditions) in Iscove's modified Dulbecco's medium (IMDM) supplemented with 20\% pretested horse serum and mouse IL-3 conditioned medium at a concentration that stimulated optimal cell growth, which corresponds to $100 \mathrm{U}$ rlL-3 per ml. FDCP-mix cells were kept in a density between $6 \times 10^{4}$ to $10^{6}$ cells $/ \mathrm{ml}$ and were carefully controlled for normal growth rates, factor dependency and differentiation. For activation of the $\mathrm{OHT}$-inducible $\mathrm{mN} 1^{\mathrm{IC}} \mathrm{FDCP}$-mix cells, 4-Hydroxy-Tamoxifen (OHT, RBI, USA) was added to the medium at the concentrations indicated. All cells were regularly checked to be free of mycoplasma contamination using a Mycoplasma PCR Elisa Kit (Roche, Germany).

Erythroid differentiation of cells was induced by washing the cells once in IMDM and plating $1 \times 10^{5} \mathrm{cells} / \mathrm{ml}$ in IMDM containing $20 \%$ pretested fetal calf serum (FCS), $5 \mathrm{U} / \mathrm{ml}$ erythropoietin (Roche, Germany) and $5 \mathrm{U} / \mathrm{ml} \mathrm{IL}-3$ (Roche, Germany). Myeloid differentiation of cells was induced by washing the cells once in IMDM and plating $1 \times 10^{5}$ cells/ml in IMDM containing $20 \%$ pretested FCS, $1000 \mathrm{U} / \mathrm{ml} \mathrm{G-CSF}$ (Neupogen, Amgen, USA), $2 \mathrm{U} / \mathrm{ml}$ IL-3 (Roche, Germany) and $250 \mathrm{U}$ recombinant murine GM-CSF per ml. ${ }^{36}$ Aliquots were removed for analysis at time points indicated. To ensure optimal growth and differentiation conditions, the cells were split to constant density and fed with fresh differentiation medium every fourth day. Viable cells were counted by trypan blue dye exclusion. Differentiation of FDCP-mix cells was monitored by FACS analyses and by morphological scoring of MayGrünwald-Giemsa and $\mathrm{O}$-Dianiside stained cytospin preparations. Considerable care was taken to validate accurate differential counts. All differential counts were done on 100-200 cells in a blinded fashion by TS and UJ.

Plasmids, stable transduction and selection procedures. To obtain clones of the $p 53^{\text {null }}$ multipotent hematopoietic progenitor cell line, ${ }^{11}$ in which translocation of the constitutive active intracellular domain of mNotch1 into the nucleus and RBP-J-dependent transactivation of target genes can be regulated, p53 $3^{\text {null }}$ FDCP-mix cells were transfected by electroporation with a retroviral vector carrying an intracellular domain of the murine Notch1 fused to the hormone-binding domain of the human estrogen receptor (rNERTneo ${ }^{9}$ ) and stable cell lines were established by G418 selection. As a control, cells were transfected with the retroviral vector alone $\left(\mathrm{rne}^{9}\right)$. Cell clones derived from three independent transfections were used in this study. To obtain p53 ${ }^{\text {null }}$ NERTneo cells, which express functional p53 $3^{\text {wt }}$, a DNA fragment containing the $p 53^{\mathrm{wt}}$ gene was subcloned into the pCAGexpression vector carrying the puromycin resistance gene, ${ }^{15}$ and cells were transfected by electroporation or nucleofection (Amaxa, Germany). In brief, $5 \times 10^{6}$ cells were either electroporated as described previously ${ }^{9}$ or nucleofected with $1 \mu \mathrm{g}$ pCAG-p53 in solution R with program W-01. Mass cultures were selected with $0.5-$ $2.0 \mu \mathrm{g}$ Puromycin for 3-21 days and clonal cell lines were established after 3 weeks by cloning in soft agar in the presence of $2.0 \mu \mathrm{g}$ Puromycin. Mass cultures were analyzed 3 days (CFSE staining) or 3 weeks $\left({ }^{3} \mathrm{H}\right]$ thymidine incorporation) after transfection.

FACS analyses. Phycoerytrin (PE)- and Allophycocyanin (APC)-conjugated monoclonal antibodies directed against Ly76 (clone Ter119) and CD11b (Mac-1, clone $\mathrm{M} 1 / 70$ ), respectively, or their respective isotype controls were used (all Pharmingen, Europe). Cells were harvested by centrifugation and resuspended in PBS containing 3\% FCS. Fc-Block (\#01241D, Pharmingen, Europe) was added at a dilution of $1: 100$ for $5 \mathrm{~min}$ at room temperature (RT). Subsequently, antibodies were added at a dilution of $1: 100$. After an incubation for $20 \mathrm{~min}$ at RT in the dark, cells were washed and resuspended in PBS containing $1 \%$ FCS and $1 \mu \mathrm{g} / \mathrm{ml}$ propidium iodide or 7AAD for dead cell exclusion. FACS analysis was done with a Becton Dickinson FACSCalibur machine and Cell Quest software, or a Becton Dickinson FACSCanto machine and FACSDiva software using standard procedures.
Reporter constructs, transient transfections and luciferase assays. Cells $\left(5 \times 10^{6}\right)$ were transiently transfected by electroporation ${ }^{9}$ and luciferase reporter assays ${ }^{8}$ were done as described. The following constructs were used: For control of Notch activation: $1 \mu \mathrm{g}$ of (RBP-J RE)12-Luc (pGa981-6, firefly luciferase reading frame under the control of a minimal $\beta$-globin promoter and 12 RBP-J-binding sites ${ }^{37}$ ); for transactivation of the 21 promoter: $18 \mu \mathrm{g}$ of p21luc, which carries a firefly luciferase gene under the control of the $-2.2 \mathrm{~kb}$ human $p 21$ promoter; ${ }^{38}$ for transactivation of the mdm promoter: $18 \mu \mathrm{g}$ of mdm2luc, which carries a firefly luciferase gene under control of the $-350 \mathrm{bp}$ human $\mathrm{mdm} 2$ promoter; ${ }^{38}$ and either $0.1 \mu \mathrm{g}$ phRL-CMV plasmids or $3 \mu \mathrm{g}$ pTK-renilla plasmids (constitutive expression of Renilla-luciferase for transfection efficiency control), respectively. Cells were treated with different concentrations of $\mathrm{OHT}$ as indicated and measurements of luciferase activities were performed using the Dual Luciferase Kit (Promega) according to manufacturers instructions.

Mutation of the RBP-J binding site. Mutation of the RBP-J binding site within the p21-promoter (p21RBP-Jmut) was performed by a three-step sitedirected PCR mutagenesis using the primers p21mut for $\left(5^{\prime}\right.$-gagggatcacacc gtctagaggtgatattgtggg- $\left.3^{\prime}\right)$, p21mut rev ( $5^{\prime}$-tcacctctagacggtgtgatccctcactaggtca- $\left.3^{\prime}\right)$, Nhel for $\left(5^{\prime}\right.$-cggtcccggaacctcgcgtgctgcagagg- $\left.3^{\prime}\right)$ and Pstl rev ( $5^{\prime}$-tacgcgtgctagccc gggctc- $3^{\prime}$ ) and the plasmid p21luc as a template. Deletion of the p53 binding sites was performed by the same method using the primers p53BS1 for $\left(5^{\prime}\right.$-ggccattagagctctggcatagaagag- $\left.3^{\prime}\right)$, p53BS1 rev $\left(5^{\prime}\right.$-gccagagctctaatggccagaaag cca- $\left.3^{\prime}\right)$, Xhol for ( $5^{\prime}$-tcttacgcgtgctagcccgggctcgagatc- $\left.3^{\prime}\right)$, and Avalll rev ( $5^{\prime}$-caag cacacatgcatcagatcc- $3^{\prime}$ ) for deletion of the first p53 binding site and primers p53BS2 for $\left(5^{\prime}\right.$-agaggaagagagattccagactctga- $\left.3^{\prime}\right)$, p53BS2 rev $\left(5^{\prime}\right.$-ggaaatctctctcctctaacgca gct- $\left.3^{\prime}\right), P s t$ rev and Nhel for for deletion of the second p53 binding site. Mutation of the RBP-J binding site and deletion of the p53 binding sites were confirmed by sequencing.

CFSE-assay. Cells $\left(5 \times 10^{6}\right)$ were incubated with CFSE (Sigma, Munich) at a final concentration of $5 \mu \mathrm{M}$ in $1 \mathrm{ml} \mathrm{PBS}$ containing $0.1 \% \mathrm{BSA}$ for $5 \mathrm{~min}$ at $37^{\circ} \mathrm{C}$. The reaction was stopped by adding $10 \mathrm{ml}$ cold-medium containing $20 \%$ horse serum and incubation on ice for $5 \mathrm{~min}$. The cells were washed two times and resuspended at a concentration of $2 \times 10^{5} \mathrm{celll} / \mathrm{ml}$ in self-renewal medium in the presence or absence of $500 \mathrm{nM}$ OHT. Proliferation was analyzed after 3 days by FACS analysis.

$\left[{ }^{3} \mathrm{H}\right]$-thymidine incorporation. Cells were plated in self-renewal medium at either $6 \times 10^{4}$ or $1 \times 10^{5}$ per $\mathrm{ml}$ in the absence or presence of $500 \mathrm{nM} \mathrm{OHT}$. After 24 or $48 \mathrm{~h},\left[{ }^{3} \mathrm{H}\right]$ thymidine incorporation was measured as described previously. ${ }^{7}$ Data are expressed as mean counts per minute of triplicate wells \pm S.D.

ChIP assay. The ChIP was performed as described previously ${ }^{39}$ with slight modifications. Briefly, $6.5 \times 10^{7} \mathrm{FDCP}$-mix cells (A7rNERTneo24 cells) were induced or not induced for $8 \mathrm{~h}$ with $500 \mathrm{nM} \mathrm{OHT}$, washed with PBS and resuspended in $1.5 \mathrm{ml}$ SDS lysis buffer (1\% SDS, $10 \mathrm{mM}$ EDTA, $50 \mathrm{mM}$ Tris-HCl, $\mathrm{pH}$ 8.1) plus Complete protease inhibitor (Roche). To confirm the induction of the Notch-signaling pathway, the upregulation of Hes1 and Hey1 transcripts was checked by real-time PCR as described previously ${ }^{40}$ (data not shown). $2 \times 400 \mu \mathrm{l}$ of the lysate were sonified and precleared with $70 \mu \mathrm{l}$ Protein A (Upstate, Charlottesville, VA, USA)/Protein G (Active Motif, Carlsbad, CA, USA) agarose beads mix (1:1, Salmon Sperm saturated) for $1 \mathrm{~h}$ at $4{ }^{\circ} \mathrm{C} .10 \mu \mathrm{g}$ of anti-p53 antibody (Pab240) or $10 \mu \mathrm{g}$ anti-mouse IgG (Active Motif) were added as a control, incubated for $1 \mathrm{~h}$ at $4^{\circ} \mathrm{C}$, and $150 \mu \mathrm{l}$ Protein A/G slurry mix were added overnight. Additionally, samples were spiked with $100 \mathrm{ng}$ of pUC18 vector DNA as an external control for recovery. The beads were washed and crosslinks were reversed as described in the Upstate ChIP protocol. DNA was purified using the ChIP-IT purification columns (Active Motif) and eluted in a $100 \mu \mathrm{l} \mathrm{H}_{2} \mathrm{O}$. Five microliter of this DNA were measured either in a semi-quantitative PCR using the Multiplex PCR Kit-100 (Qiagen, Hilden, Germany) in $50 \mu$ l or in a real-time PCR using FastStart Universal SYBR Green Master Mix (Rox) (Roche Diagnostics, Mannheim, Germany) in a $10 \mu$ l volume. Primers for p53-binding site within the p21 promoter at a final concentration of $100 \mathrm{nM}$ were: BS1 forward: $5^{\prime}$-cccttggatttcctttctatcag-3'; BS1 reverse: $5^{\prime}$-gtagttgggtatcatcaggtctcc-3'; BS2 forward: $5^{\prime}$-tgtgttctgaacaggatgagg- $3^{\prime}$; BS2 reverse: $5^{\prime}$-tgagttctgacatctgctctcc- $3^{\prime}$; control BS (no p53 binding) forward: $5^{\prime}$ gttcatagatgtatgtggctctgc-3'; control BS reverse: $5^{\prime}$-gtcgagctgcctccttatagc-3'; pUC forward: $5^{\prime}$-aagttggccgcagtgttatc- $3^{\prime}$; pUC reverse: $5^{\prime}$-tttgccttcctgttttgct- $3^{\prime}$. For semiquantitative PCR BS1, BS2, and control BS were cycled 36 times and pUC was cycled 28 times (protocol on request). 
Western Blotting. Cell were cultured under self-renewal conditions and in the presence or absence of $500 \mathrm{nM} \mathrm{OHT}$. Harvesting, electrophoresis and Western Blotting of protein extracts were performed as described previously. ${ }^{9}$ Ten micrograms of protein was separated per lane. Antibodies specific for p21 (sx-118, Pharmingen/BectonDickinson, Heidelberg, Germany), $\beta$-actin (C2, Santa Cruz Biotechnology, CA, USA) or estrogen receptor (SC-8002, Santa Cruz) were used. The detected proteins were visualized by the ECL system (Amersham Pharmacia Biotec, UK). For control of the ChIP assay $25 \mu \mathrm{l}$ of the Protein A/G slurry were incubated in SDS loading buffer and half of it were used for a Western blot. Pab240 anti-p53 antibody $(1 \mathrm{ng} / \mathrm{ml})$ was used to detect the precipitated p53.

Statistical analysis. Statistical differences were assessed using the Student's t-test for paired data.

Acknowledgements. We thank Silke Horn, Cornelia Kuklik-Roos and Gabriele Warnecke for expert technical support and Elaine Spooncer and Michael Dexter for the p53 null FDCP-mix cell lines. This work was supported by the Deutsche Forschungsgemeinschaft (Priority Program 1109 'Stem Cells' and SFB 415 'Signal Transduction' project B8 to UJ). This report represents a part of the doctoral thesis by $\mathrm{KH}$ and of the diploma thesis of $\mathrm{JH}$.

1. Wilson A, Radtke F. Multiple functions of Notch signaling in self-renewing organs and cancer. FEBS Lett 2006; 580: 2860-2868.

2. Lai EC. Notch signaling: control of cell communication and cell fate. Development 2004 131: 965-973.

3. Hurlbut GD, Kankel MW, Lake RJ, Artavanis-Tsakonas S. Crossing paths with Notch in the hyper-network. Curr Opin Cell Biol 2007; 19: 166-175.

4. Honjo T. The shortest path from the surface to the nucleus: RBP-J kappa/Su(H) transcription factor. Genes Cells 1996; 1: 1-9.

5. Huang Q, Raya A, DeJesus P, Chao S-H, Quon K, Caldwell J et al. Identification of p53 regulators by genome-wide functional analysis. Proc Natl Acad Sci USA 2004; 101 : 3456-3461.

6. Vogelstein B, Lane D, Levine A. Surfing the p53 network. Nature 2000; 408: 307-310.

7. Schroeder $T$, Just $U$. $m$ Notch1 signaling reduces proliferation of myeloid progenitor cells by altering cell-cycle kinetics. Exp Hematol 2000; 28: 1206-1213.

8. Schroeder T, Kohlhof H, Rieber N, Just U. Notch signaling induces multilineage myeloid differentiation and up-regulates Pu.1 expression. J Immunol 2003; 170: 5538-5548.

9. Schroeder T, Just U. Notch signalling via RBP-J promotes myeloid differentiation. EMBO J 2000; 19: 2558-2568.

10. Spooncer E, Heyworth CM, Dunn A, Dexter TM. Self-renewal and differentiation of interleukin-3-dependent multipotent stem cells are modulated by stromal cells and serum factors. Differentiation 1986; 31: 111-118.

11. Pierce A, Spooncer E, Wooley S, Dive C, Francis J, Miyan J et al. Bcr-Abl protein tyrosine kinase activity induces a loss of p53 protein that mediates a delay in myeloid differentiation. Oncogene 2000; 19: 5487-5497.

12. Just U, Stocking C, Spooncer E, Dexter TM, Ostertag W. Expression of the GM-CSF gene after retroviral transfer in hematopoietic stem cell lines induces synchronous granulocytemacrophage differentiation. Cell 1991; 64: 1163-1173.

13. Just U, Boettiger D, Kan O, Dexter TM, Spooncer E. Insertional mutagenesis as a route to identifying genes involved in self renewal of haemopoietic stem cells. Curr Top Microbiol Immunol 2000; 251: 27-34

14. Lyons A, Parish C. Determination of lymphocyte division by flow cytometry. J Immuno Methods 1994; 171: 131-137.

15. Niwa H, Masui S, Chambers I, Smith AG, Miyazaki J. Phenotypic complementation establishes requirements for specific POU domain and generic transactivation function of Oct-3/4 in embryonic stem cells. Mol Cell Biol 2002; 22: 1526-1536.

16. Sherr $C$, Roberts J. CDK inhibitors:positive and negative regulators of $G_{1}$-phase progression. Genes Dev 1999; 13: 1501-1512.

17. El-Deiry WS, Tokino T, Velculescu VE, Levy DB, Parsons R, Trent JM et al. WAF1, a potential mediator of p53 tumor suppression. Cell 1993; 75: 817-825.
18. Rangarajan A, Talora $\mathrm{C}, \mathrm{Okuyama} \mathrm{R}$, Nicolas $\mathrm{M}$, Mammucari $\mathrm{C}$, Oh $\mathrm{H}$ et al. Notch signaling is a direct determinant of keratinocyte growth arrest and entry into differentiation. EMBO J 2001; 20: 3427-3436.

19. Tun T, Hamaguchi $Y$, Matsunami N, Furukawa $T$, Honjo $T$, Kawaichi M. Recognition sequence of a highly conserved DNA binding protein RBP-J. Nucleic Acids Res 1994; 22: 965-971.

20. Henning K, Schroeder T, Schwanbeck R, Rieber N, Bresnick EH, Just U. mNotch1 signalling and erythropoietin cooperate in erythroid differentiation of multipotent progenitor cells by upregulation of b-globin. Exp Hematol 2007; 35: 1321-1332.

21. Allan LA, Duhig T, Read M, Fried M. The p21(WAF1/CIP1) promoter is methylated in Rat-1 cells; stable restoration of p53-dependent p21 (WAF1/CIP1) expression after transfection of a genomic clone containing the p21(WAF1/CIP1) gene. Mol Cell Biol 2000; 20: $1291-1298$

22. Qi R, An H, Yu Y, Zhang M, Liu S, Xu H et al. Notch1 signaling inhibits growth of human hepatocellular carcinoma through induction of cell cycle arrest and apoptosis. Cancer Res 2003: 63: 8323-8329

23. Talora C, Cialfi S, Segatto O, Morrone S, Kim Choi J, Frati L et al. Constitutively active Notch1 induces growth arrest of HPV-positive cervical cancer cells via separate signaling pathways. Exp Cell Res 2005; 305: 343-354.

24. Yang X, Klein R, Tian X, Cheng HT, Kopan R, Shen J. Notch activation induces apoptosis in neural progenitor cells through a p53-dependent pathway. Dev Biol 2004; 269: 81-94.

25. Ong C-T, Cheng H-T, Chang L-W, Ohtsuka T, Kageyama R, Stormo G et al. Target selectivity of vertebrate Notch proteins: collaboration between discrete domains and CSL-binding site architecture determines activation probability. J Biol Chem 2006; 281: 5106-5119

26. Mammucari C, Tommasi di Vignano A, Sharov A, Neilson J, Havrda M, Roop D et al. Integration of Notch1 and calcineurin/NFAT signaling pathways in keratinocyte growth and differentiation control. Dev Cell 2005; 8: 665-676.

27. Xu Y. Regulation of p53 responses by post-translational modifications. Cell Death Diff 2003; 10: 400-403.

28. Knights CD, Catania J, Di Giovanni S, Muratoglu S, Perez R, Swartzbeck A et al. Distinct p53 acetylation cassettes differentially influence gene-expression patterns and cell fate. $J$ Biol Chem 2007: 173: 533-544.

29. Kim SB, Chae GW, Park J, Tak H, Chung JH, Park TG et al. Activated Notch1 interacts with p53 to inhibit its phosphorylation and transactivation. Cell Death Diff 2007; 14: 982-991.

30. Nair P, Somasundaram K, Krishna S. Activated Notch1 inhibits p53-induced apoptosis and sustains transformation by human papillomavirus type $16 \mathrm{E} 6$ and $\mathrm{E} 7$ oncogenes through a PI3K-PKB/Akt-dependent pathway. J Virol 2003; 77: 7106-7112.

31. Mungamuri $S$, Yang $X$, Thor $A$, Somasundaram $K$. Survival signaling by Notch1:mammalian target of rapamycin (mTOR)-dependent inhibition of p53. Cancer Res 2006; 66: 4715-4724.

32. Beverly L, Felsher D, Capobianco A. Suppression of $p 53$ by Notch in lymphomagenesis: implications for initiation and regression. Cancer Res 2005; 65: 7159-7168.

33. Cheng T, Rodrigues N, Shen H, Yang Y, Dombkowski D, Sykes M et al. Hematopoietic stem cell quiescence maintained by p21cip1/waf1. Science 2000; 287: 1804-1808.

34. van Os B, Kamminga L, Ausema A, Bystrykh L, Draijer D, van Pelt $K$ et al. A limited role for p21cip 1/waf1 in maintaining normal hematopoietic stem cell function. Stem Cells 2007; 25: 836-843.

35. TeKippe M, Harrison DE, Chen J. Expansion of hematopoietic stem cell phenotype and activity in Trp53-null mice. Exp Hematol 2003; 31: 521-527.

36. Schroeder T, Lange $\mathrm{C}$, Strehl J, Just U. Generation of functionally mature dendritic cells from the multipotential stem cell line FDCP-mix. Br J Haematol 2000; 111: 890-897.

37. Strobl LJ, Hofelmayr H, Stein C, Marschall G, Brielmeier M, Laux G et al. Both Epstein-Barr viral nuclear antigen 2 (EBNA2) and activated Notch1 transactivate genes by interacting with the cellular protein RBP-J kappa. Immunobiology 1997; 198: 299-306.

38. Kim E, Rohaly G, Heinrichs S, Gimnopoulos D, Meißner H, Deppert W. Influence of promoter DNA topology on sequence-specific DNA binding and transactivation by tumor suppressor p53. Oncogene 1999; 18: 7310-7318.

39. Kim E, Günther W, Yoshizato K, Meissner H, Zapf S, Nüsing RM et al. Tumor suppressor p53 inhibits transcriptional activation of invasion gene thromboxane synthase mediated by the proto-oncogenic factor ets-1. Oncogene 2003; 22: 7716-7727.

40. Schroeder T, Meier-Stiegen F, Schwanbeck R, Eilken H, Nishikawa S, Häsler R et al Activated Notch1 alters differentiation of embryonic stem cells into mesodermal cell lineages at multiple stages of development. Mech Dev 2006; 123: 570-579. 